\title{
ASPEK LEGALITAS PENYIMPANAN MINUTA AKTA NOTARIS SECARA ELEKTRONIK
}

\author{
Naily Zahrotun Nisa' \\ Magister Kenotariatan Universitas Surabaya, Indonesia \\ Email : nailyzahrotunnisa@gmail.com
}

\begin{abstract}
ABSTRAK
Penelitian ini bertujuan untuk (1) menjelaskan makna keautentikan dari segi hukum perdata Belanda dan Indonesia, (2) menjelaskan aspek legalitas serta mekanisme penyimpanan minuta akta secara elektronik di Indonesia, (3) menjelaskan kekuatan pembuktian minuta akta elektronik di muka pengadilan. Metode penelitian yang digunakan adalah yuridis normatif dengan cara menelaah teori, konsep hukum serta peraturan perundang-undangan yang berkaitan dengan penelitian ini. Hasil penelitian menunjukkan bahwa minuta akta notaris yang disimpan secara elektronik dapat terjaga keautentikan dan keamanannya. Solusinya dengan adanya harmonisasi antara regulasi dan teknologi yang didukung adanya sistem identifikasi dan autentikasi yang akuntabel. hal tersebut dapat merujuk pada penyelenggaraan keautentikan dokumen di Belanda dengan harmonisasi ketentuan regional uni eropa berupa peraturan nomor 910 tahun 2014 tentang e-identification and trust services.
\end{abstract}

Kata Kunci: Akta Notaris Elektronik; Keauntentikan; Aspek Yuridis.

\section{ABSTRACT}

This study aims to (1) explain the meaning of authenticity based on Dutch and Indonesian civil law, (2) explain the legality aspect and mechanism of electronic storage of notary deed in Indonesia, (3) explain the evidentiary power of Elektronic notary deed in front of the judiciary. The research method used is juridical normative by examining theories, legal concepts and laws and regulations related to this research. The results showed that the authenticity and safety of notary deeds stored electronically could be maintained. The solution is by harmonizing regulations and technology, which is supported by an accountable identification and authentication system. This can refer to the implementation of document authenticity in the Netherlands with the harmonization of European Union regional provisions in the form of regulation number 910 of 2014 concerning e-identification and trust services.

Keywords: Electronic Notary Deed; Accountability; Juridical Aspects.

\section{PENDAHULUAN}

Minuta Akta Notaris merupakan arsip negara yang harus dipelihara secara hati-hati agar tetap terjaga mutu dan kualitasnyasebagaialatbuktisempurnadan terkuat. Penyimpanan serta pemeliharaan akta tersebut menjadi tanggung jawab notaris sebagaimana amanat pasal 1 angka 13 Undang- Undang Nomor 30 Tahun 2004 tentang Jabatan Notaris sebagaimana telah diubah dengan Undang-Undang Nomor 2 Tahun 2004 (selanjutnya disebut UUJN). Artinya, selama minuta akta disimpan dan dipelihara oleh notaris, maka segala konsekuensi yang timbul menjadi tanggung jawab dari notaris yang bersangkutan. Namun, secara yuridis akta tersebut tidak hanya disimpan oleh Notaris, ada beberapa ketentuan dalam UUJN yang mengharuskan minuta akta disimpan oleh Majelis Pengawas Daerah (MPD).

Berdasarkan Pasal 63 ayat (5) UUJN, minuta akta yang telah berumur lebih dari 25 (dua puluh lima) tahun dapat diserahkan kepada MPD untuk disimpan. Namun secara praktis, MPD belum mampu menyimpan dan memelihara ribuan minuta akta karena tidak memiliki ruang khusus untuk menyimpan arsip tersebut (Rositawati dkk, 2017). Sehingga penyimpanan tetap dikembalikan kepada 
Notaris untuk disimpan hingga masa jabatannya berakhir (pensiun). Ketentuan pasal tersebut belum dilaksanakan sebagaimana seharusnya.

Praktek pengarsipan yang dilakukakan didalam dunia kenotariatan sampai saat ini masih menggunakan media konvensional berbentuk kertas dan disimpan secara manual. Penyimpanan secara fisik dengan kurun waktu lama, seringkali rawan hilang dan terjadi kerusakan. Seperti ketika kantor notaris pindah tempat, seringkali banyak berkas atau minuta tercecer dan hilang, faktor minimnya tempat penyimpanan sehingga banyak berkas notaris yang berserakan, kebakaran dan bencana alam (Imtiyaz dkk, 2020). Hilang dan rusaknya minuta akta tidak diakomodir secara baik didalam UUJN sehingga menimbulkan problematika dikemudian hari pada kepentingan klien (Triyanti, 2015).

Beberapa pakar hukum mengatakan bahwa pelayanan jasa hukum Notaris Indonesia terkesan lamban dalam menyikapi situasi diatas. Padahal di era digitalisasi, Notaris dapat memanfaatkan teknologi untuk memudahkan pekerjaan terutama dibidang pelayanan hukum dan pengarsipan. Namun, Notaris terkesan khawatir dan takut untuk bertranformasi diri.

Alasan yang melatarbelakangi kekhawatiran Notaris Indonesia adalah regulasi yang mengharuskan adanya bukti fisik akta dan bukan secara elektronik, sebagaimana ketentuan UUJN serta pasal 5 ayat (4) UU ITE yang mengecualikan akta notaris sebagai alat bukti sah di dalam konteks dokumen elektronik, sehingga apabila tetap diimplementasikan dapat menimbulkan konflik hukum bagi notaris, baik secara perdata, administratif dan pidana (Makarim, 2020).

Selain itu, kekhawatiran terkait konsekuensi hukum yang timbul dari implementasi penyimpanan minuta akta elektronik bagi notaris, yaitu : (i) turunnya keautentikan akta notaris menjadi akta dibawah tangan, (ii) berpotensi bocor sehingga melanggar asas kerahasiaan, (iii) rawan diubah-ubah karena tidak ada jaminan keamanan sistem. (iv) kemungkinan adanya penampikan dari pihak lain, (v) rawan gugatan dari klien notaris, (vi) dan berpotensi melanggar kode etik dengan sanksi pemberhentian dari jabatannya sebagai notaris karena tidak mematuhi aturan yang ada (Makarim, 2020). Selain itu, minuta akta elektronik akan membuat sukar para hakim dalam menyelesaikan dan memutus sengketa apabila minuta tersebut dijadikan sebagai alat bukti (Apriana, 2018).

Walaupun didalam substansi UUJN dan UU ITE belum mengakui keautentikan minuta akta elektronik, namun setidaknya pada ketentuan Pasal 155 ayat (3) UUJN Perubahan memberikan kewenangan bagi notaris mengenai cybernotary, yaitu untuk melakukan sertifikasi transaksi secara elektronik (Makarim, 2015). Makna mensertifikasi yaitu Notaris dapat memberikan layanan keterpercayaan yang mendukung sistem keautentikan dari suatu transaksi elektronik dan hal tersebut bisa dihubungkan dengan Pengaturan sistem elektronik dan Transaksi Elektronik yang ada di Indonesia (Makarim, 2020). Selain itu dapat pula melihat serta merujuk pada implementasi pelayanan keterpercayaan terhadap keautentikan dokumen elektronik di Belanda dengan harmonisasi ketentuan regional uni eropa berupa peraturan nomor 910 tahun 2014 tentang e-identification and trust services. Berdasarkan analisis Edmon Makarim (2015) seorang Pakar Telematika Universitas Indonesia menjelaskan bahwa harmonisasi regulasi dan implementasi terkait aturan tersebut berjalan secara baik. Keautentikan dari dokumen elektronik di Belanda telah diakui secara formil maupun materiil. Karena terdapat sistem keterpercayaan yang akuntabel dan reliable. Sehingga aspek legalitas dan kepastian hukum dokumen elektronik tersebut dapat terjamin. 
Agar penyimpanan minuta akta elektronik dapat dilaksanakan sebagai bentuk pemberlakuan cyber notary maka perlunya rekonstruksi hukum dan dukungan sebuah teknologi dengan sistem identifikasi dan autentikasi yang akuntabel dan terpercaya. Hal tersebut sebagai bentuk pemanfaatan teknologi di era revolusi industry 4.0 dan sosial 5.0. Sehingga Notaris tidak terkesan tertinggal dengan pejabat publik lainnya. Dari konsep tersebut cukup meminimalisir kekhawatiran dari Notaris Indonesia dalam bertransfomasi diri menuju cyber notary. Sehingga akta notaris dimasa yang akan datang dapat dibuat dan disimpan secara elektronik. Sedangkan untuk akta konvensional yang telah dibuat sebelumnya, dapat di lakukan proses elektronik untuk disimpan, dengan tujuan sebagai back up data.

Penelitian ini merujuk pada penelitian-penelitian terdahulu, dimana substansinya dianggap masih relevan dan mempunyai hubungan/keterkaitan dengan penelitian yang ditekuni oleh penulis. Beberapa penelitian tersebut, yaitu : pertama, Keautentikan Dokumen Publik Elektronik dalamAdminitrasi Pemerintahan dan Pelayanan Publik (Makarim, 2015), perbedaan dengan penelitian penulis adalah objek pembahasan menyangkut lingkup administrasi pemerintahan dan pelayanan publik sedangkan penelitian penulis lingkupnya pada dunia kenotariatan. Persamaannya yaitu sama-sama membahas mengenai keautentikan dokumen elektronik. Kedua, Urgensi Penyimpanan Protokol Notaris dalam Bentuk Elektronik dan Kepastian Hukumnya di Indonesia (Kuswanto, 2017) Perbedaannya, penelitian tersebut membahas mengenai urgensi penyimpan seluruh protokol notaris yang berbentuk hardcopy kemudian disimpan ke dalam media elektronik sedangkan penulis membahas secara khusus mengenai urgensi penyimpanan minuta akta baik dari bentuk media cetak ke media elektronik ataupun minuta akta yang dari awal dibuat secara elektronik.
Persamaannya, keduanya membahas mengenai urgensi penyimpanan minuta elektronik dan aspek legalitasnya. Ketiga, Kedudukan Hukum Salinan Akta Notaris Dalam Hal Terjadi Musnahnya Minuta Akta (Priyandini, 2018) Perbedaannya, penelitian tersebut membahas aspek hukum salinan akta konvensional, sedangkan penulis membahas aspek hukum salinan akta elektronik. Persamaannya, keduanya membahas terkait pentingnya salinan akta sebagai alat bukti dipersidangan. Keempat, Legalitas Alat Bukti Elektronik Dalam Sistem Peradilan Pidana (Pribadi, 2018) Perbedaannya, penelitian tersebutmembahas legalitas alat bukti pidana sedangkan penulis membahas legalitas alat bukti perdata. Persamaannya, keduanya membahas kekuatan alat bukti elektronik dimuka pengadilan. Kelima, Prospek Cyber Notary Sebagai Media Penyimpanan Pendukung Menuju Profesionalisme Notaris (Syamsir, Rahmi, \& Yetniwati, 2019) Perbedaannya, penelitian tersebut lebih membahas peran notaris dibidang cyber notary mengenai penyimpanan pendukung protokol notaris dari media cetak ke media elektronik sedangkan penulis membahas terkait konsep penyimpanan dari minuta akta yang dibuat secara elektronik dan minuta akta berupa media cetak yang disimpan ke media elektronik. Persamaannya, keduanya membahas mengenai peran notaris dalam memanfaatkan teknologi di era digital dengan memberikan konsep penyimpanan minuta akta elektronik.

Berdasarkan penjelasan diatas, penulis mencermati bahwa penelitian-penelitian diatas banyak membahas mengenai penyimpanan protokol notaris dari media kertas ke media elektronik serta legalitasnya dan belum ada penelitian spesifik terkait penyimpanan minuta akta yang dibuat secara elektronik dengan mekanisme penyimpanan dan pembuatan yang terautentikasi dan teridentifikasi secara akuntabel. Selain itu, penulis juga membahas mengenai undang- 
undang dan peraturan lain Indonesia dan regulasi Belanda yang mengakui keautentikan dokumen elektronik sebagai alat bukti yang sah sehingga dapat dijadikan bahan rujukan apabila dikemudian hari notaris benar-benar berinovasi ke arah digitalisasi. Dengan tujuan agar minuta akta yang dibuat dan disimpan secara elektronik memilki keabsahan yang melekat. Oleh sebab itu, inilah perbedaan penelitian penulis dengan penelitianpenelitian sebelumnya yang telah ada.

\section{METODE}

Metode penelitian ini adalah yuridis normatif yaitu penelitian yang dilakukan berdasarkan bahan pustaka atau dapat disebut sebagai penelitian kepustakaan (Mamudji, 2005) dan bersifat kualitatif. Pendekatan yang digunakan dalam penelitian ini adalah pendekatan perundang-undangan (statute approach) serta pendekatan konseptual (conseptual approach). Pendekatan Perundang-undangan dilakukan dengan meneliti semua norma hukum serta regulasi yang memiliki keterkaitan dengan penelitian ini, sedangkan pendekatan konseptual dilakukan dengan bersandar pada pandangan-pandangan dan doktrin-doktrin ilmu hukum yang berkembang guna membangun argumentasi hukum dalam memecahkan masalah terkait isu hukum yang dibahas oleh penulis. (Marzuki, 2011)

Penelitian hukum tidak mengenal suatu data, sebab penelitian ini didasarkan pada studi kepustakaan dan bukan lapangan, sehingga ia dikenal sebagai bahan hukum (Marzuki, 2011). Bahan Hukum yang menjadi rujukan dalam penelitian ini ada 3 (tiga) yaitu (i) sumber hukum primer yang terdiri dari peraturan perundang-undangan dan surat edaran instansi hukum (ii) sumber hukum sekunder yaitu literatur-literatur hukum, jurnal-jurnal hukum, artikel-artikel hukum, pendapat para sarjana, tesis dan bahan yang diperoleh dari internet yang memiliki kaitan dengan penelitian ini, dan (iii) sumber hukum tersier yang terdiri dari kamus besar bahasa indonesia dan kamus hukum.

Metode pengumpulan bahan hukum pada penelitian ini menggunakan model content analysis yaitu meneliti dokumen data berupa teks, simbol, dan lain-lain dengan cara membaca, menganalisis, kemudian menginventarisasi,mengidenti fikasi, mengklasifikasikan dan menyusun bahan hukum, serta melakukan pencarian melalui media internet yang berkaitan dengan aspek regulasi dan mekanisme penyimpanan akta notaris secara elektronik. Menurut Klaus Krippendorff Conten analysis memberikan keuntungan, yaitu selain memperoleh isi materi sebagai obyeknya, pembaca memperoleh wawasan terkait dengan konsepsi-konsepsi yang lebih baru tentang gejala-gejala simbolik (Subrayogo, 2001).

Teknik analisis bahan hukum pada penelitian ini menggunakan metode deduktif yaitu berpangkal pada pernyataan bersifat umum kemudian dijabarkan ke penyataan yang bersifat khusus, selanjutnya ditarik sebuah kesimpulan (Marzuki, 2011).

\section{HASIL DAN PEMBAHASAN \\ Makna Keautentikan Berdasarkan Hukum Perdata Indonesia dan Belanda}

Ditinjau dari historisnya, Indonesia berdasarkan asas konkordansi telah menerapkan warisan hukum Belanda salah satunya yaitu burgelijk wetboek atau dalam Bahasa Indonesia dikenal dengannKitab Undang-Undang Hukum Perdata. Hukum perdataamilik Belanda saat ini berbeda dengan Hukum Perdata di Indonesia. Pada hukum perdata Belanda banyak substansi dan struktur aturannya yang telah diubah, sedangkan di Indonesa pembaharuan aturan tidak dilakukan di KUHPerdatanya melainkan membentuk produk hukum nasional berupa undang-undang.

Berdasarkan penjelasan diatas, maka paradigma keautentikan berdasarkan 
masing-masing hukum perdata di kedua negara tersebut dapatlah berbeda. Karena dipengaruhi oleh aturan yang berbeda pula. Oleh karena itu berikut penjelasan mengenai paradigma keautentikan yang ditinjau dari hukum perdata Indonesia dan Belanda.

Keautentikan mengenai suatu akta atau dokumen tertulis terdapat beberapa pandangan yang berbeda, terutama dalam makna khusus keautentikan itu sendiri. Paradigma keautentikan dapat dilihat dari 2 (dua) perspektif yaitu hukum dan teknis (Makarim, 2015). Makna keautentikan berdasarkan segi teknis dilihat berdasarkan aspek materiil yaitu dengan memperhatikan bagaimana proses autentikasi terhadap identitas, dokumen atau perangkat. Sedang kan makna keautentikan dari segi hukum, di lihat berdasarkan objek yaitu bukti tulisan yang secara hukum terjamin formalitasnya, sehingga memiliki pembuktian secara sempurna, terkuat, dan subtansinya terjamin karena dibuat oleh pejabat umum yang diberi wewenang undang-undang.

Berdasarkan konteks hukum acara perdata di Indonesia, istilah keautentikan dinilai berdasarkan keobyektifan tulisan atau dokumen. Tulisan atau dokumen tersebut dapat menjadi salah satu bentuk alat bukti pada hukum perdata. Alat pembuktian yang diakui di Indonesia saat ini diatur pada pasal 1866 KUHPerdata yang meliputi Bukti Tertulis, buktisSaksi, Pengakuan, dansSumpah (Adjie, 2017). Bukti tertulis dalam Hukum Perdata Indonesia dibagi menjadi dua macam, yaitu akta autentik dan surat dibawah tangan. Berdasarkan Pasal 1868 BW menerangkan bahwa akta autentik merupakan akta yang dibuat dan ditandangani oleh pejabat yang berwenang dengan format dan tata cara yang telah diatur berdasarkan undangundang. Sedangkan surat dibawah tangan dijelaskan dalam Pasal 1874 BW yaitu surat atau tulisan-tulisan yang dibuat tanpa perantaraan pejabat umum yang berwenang. Pejabat umum tersebut meliputi jabatan Notaris sebagaimana subtansi pasal 1 angka 1 UUJN Perubahan.

Secara logis dapat dipahami bahwa kekuatan pembuktian antara akta autentik dan surat dibawah tangan memiliki bobot yang berbeda. Akta autentik nilai pembuktiannya lebih tinggi daripada akta dibawah tangan. Sehingga di dalam persidangan, majelis hakim harus meyakini bahwa bukti autentik yang dihadirkan merupakan suatu kebenaran yang tidak perlu adanya penambahan bukti lain. Sebaliknya, majelis hakim dapat mempertimbangkan akta dibawah tangan sebagai bukti kuat ataupun sekedar bukti pelengkap apabila proses pembuatan, penyimpanan, pengiriman, dan/ataupenerimaan terdapat adanya penampikan. Apabila akta dibawah tangan tersebut keberadaannya diakui dan tidak dibantah oleh para pihak yang membuatnya, maka majelis hakim dapat menerima bukti tersebut layaknya fungsi akta autentik dengan disertai penambahan bukti lain.

G.H.S Lumban Tobing (1983) memberikan penjelasan mengenai pembuktian akta autentik yang dibagi menjadi tiga kekuatan: Pertama, Kekuatan pembuktian lahiriah, artinya ia mampu membuktikan keabsahannya; Kedua, Kekuatan pembuktian formal artinya akta tersebut mendapat jaminan dari pejabat umum yang telah ditunjuk oleh undangundang terkait kebenaran formalnya; dan Ketiga, Kekuatan pembuktian material karena substansinya dianggap sebagai kebenaran untuk diberlakukan kepada semua orang. Akta autentik tidak selamanya dapat dinobatkan sebagai alat bukti yang sempurna. Akta autentik dapat menjadi akta dibawah tangan apabila ditemukan cacat berupa mekanisme atau pembuatan yang menyeleweng dari aturan undang-undang. Hal tersebut berdampak pada kekuatan eksekutorialnya yang dapat ditangguhkan menurut Hukum Acara Perdata.

Pada konteks teknis, metode keautentikan dikerjakan melalui proses digital. Artinya pengerjaan suatu dokumen 
secara elektronik harus memiliki standar keautentikan yang terukur. Pastinya standar keautentikan tersebut harus lebih kompleks dan terjamin keamanannya.

Pada minuta akta elektronik masih belum memiliki regulasi khusus, sehingga istilah minuta akta elektronik masih belum ada dan masih diragukan legalitasnya. Sehingga saat ini lebih dikenal dengan istilah dokumen eletronik. Pasal 1 ayat (4) UU ITE menerangkan bahwa Dokumen elektronik merupakan segala informasi yang dibuat atau disimpan dalam bentuk digital, analog, atau semacamnya yang bisa diperlihatkan via perangkat komputer atau sistem elektronik.

Untuk mengukur keautentikan pada dokumen elektronik perlu adanya autentikasi yang sekurang-kurangnya meliputi: Pertama, mengidentifikasi dan memastikan kebenaran identitas subyek hukum yang menyampaikan informasi; Kedua, memeriksa dan menjamin validitas dari identitas konten informasi (Makarim, 2015). Proses autentikasi terhadap Dokumen Elektronik tidak bisa berdiri sendiri sehingga perlu melibatkan: Data yang berfungsi sebagai Identitas tertentu sebagai parameter keabsahan atau identitas pihak; Otoritas pihak yang kompeten untuk melaksanakan pengecekan; adanya alat-alat tertentu; Klaim terhadap quality assurance level pada proses yang melibatkan pihak lain dan pengukuhan/ pembuktian terhadapnya; adanya jaminan keaslian dokumen/informasi (Makarim, 2015). Dari sini, dapat disimpulkan bahwa dalam menjalankan proses autentikasi, perlu adanya bantuan serta campur tangan pihak lain yang kompeten untuk melakukan proses sertifikasi, dimana pihak tersebut yang berwenang memunculkan sertifikat sebagai bentuk orisinilitas untuk menjamin keutuhan dan kebenaran suatu dokumen/ informasi elektronik di setiap prosesnya yaitu dari pembuatan hingga penyimpanan atas dokumen elektronik tersebut. Sehingga dokumen tersebut dapat dikatakan sebagai dokumen autentik.

Keautentikan secara teknis di Indonesia telah diakui dalam UU ITE yang terletak pada Bab III tentang Informasi Dokumen dan Tanda tangan elektronik. Pada pasal 5 ayat (1) dijelaskan bahwa dokumen elektronik diakui sebagai alat bukti yang sah. Dan pada pasal 5 ayat (2) disebutkan bahwa dokumen elektronik beserta hasil cetaknya adalah perluasan dari alat bukti yang dakui secara sah oleh hukum acara di Indonesia (Syamsir, Rahmi, \& Yetniwati, 2019).

Berbeda dengan hukum perdata di Indonesia, hukum perdata di Belanda telah mengalami reformasi. Alat bukti pada perdata Belanda tidak memiliki tingkat nilai pembobotan seperti di Indonesia. Seluruh alat bukti mempunyai kedudukan yang sama dan seimbang baik bukti tertulis berupa dokumen yang terdiri dari dokumen biasa (ordinary documents), dokumen pribadi (private documents), dan dokumen umum (public documents); keterangan saksi; laporan ahli serta pemeriksaan tempat (Makarim, 2015). Hakim yang selanjutnya memiliki kewenangan untuk menilai semua jenis alat bukti yang diajukan olehhpihakkyang bberperkara. Hakim Belanda lebih bersifat pasif dan memutus berdasarkan alat bukti yang telah dihadirkan. Khusus dokumen biasa atau akta otentik diminta untuk hadirkan bentuk yang orisinil di hadapan persidangan.

Selain dokumen tertulis, dokumen elektonik juga diakui di dalam hukum perdata Belanda sebagai alat bukti yang memiliki nilai pembuktian yang sama denganaalat bukti lain. Namun dengan catatan, tetap harus mempertimbangkan ketentuanketentuan yang relevan. Seperti harus memenuhi standar pengaturan dokumen elektronik berupa e-identification and e-authentication system untuk memperjelas aspek keterpercayaan terhadap keberadaan sistem pengamanannya yang berupa tanda tangan elektronik (electronic signature), 
Stempel elektronik (electronic seal), stempel waktu elektronik (electronic timestamping), layanan pengiriman terdaftar (electronic registered delivery services), dan autentikasi situs web (web-site authentication) (Makarim, 2015).

Mengenai rumusan kriteria tanda tangan elektronik, telah diatur di dalam artikel 33:15 dari Kitab Undang-Undang Hukum Perdata Belanda. Dan juga dapat dilihat pada UE 910/2014 tentang e-identification and trust services.

Keautentikan dokumen elektronik bisa dinilai berdasarkan functional equivalent approach dengan didukung oleh sistem e-identification and authentication, sebagai berikut (Makarim, 2015): (i) Dokumen yang telah ditulis dan disimpan dapat ditemukan dan dibaca kembali; (ii) e-identification, yaitu dapat dipertanggung jawabkannya dokumen elektronik tersebut atas kepastian subjek hukumnya; (iii) Dokumen yang telah disimpan dapat dijamin keutuhan isinya dari adanya resiko perubahan; (iv) Didukung adanya trust services yaitu berupa penyelenggaraan layanan jasa keterpercayaan sebagai sistem keamanan yang menjamin kebenaran proses autentikasi; (v) Adanya pengaturan terhadap penentu keautentikan dokumen guna menjaga keamanan data yang ada didalamnya, yaitu berupa Adanya penyelenggaraan suatu metode keautentikan yang reliable melalui pengembangan sistem pengamanan informasi dan komunikasi sehingga tidak memungkinkan adanya bantahan dari pihak yang membuat atau mengirimkan dokumen dan juga penerima dokumen, seperti adanya sertifikat elektronik untuk memberi kejelasan terkait penggunaan tanda tangan elektronik yang dilakukan oleh pihak ketiga secara terpercaya berupa e-Identification yaitu memastikan bahwa identitas elektronik yang dipakai merupakan identitas yang benar adanya dan e-Autenthication yaitu memastikan kevalidan dari sistem keamanan yang dipakai (e-sign, eseal, time-stamping, registered delivery services dan web-site authentication).

\section{Aspek Legalitas Serta Mekanisme Penyimpanan Minuta Akta Secara Elektronik dan Kekuatan Pembuktiannya Di Indonesia}

Legalitas menurut Buku Kamus Besar Bahasa Indonesia memiliki arti keabsahan (Suharso \& Retnoningsih, 2014). Penjelasan makna keabsahan berdasarkan Kamus hukum disamakan dengan kepastian hukum yang memiliki kaitan dengan teori positivis di Indonesia. Bahwasanya suatu perbuatan atau aktivitas hukum dikatakan sah apabila terdapat aturan tertulis berupa undang-undang (Simorangkir dkk, 2013).

Akta autentik berdasarkan ketentuan undang-undang dibuat guna menciptakan kepastian dan perlindungan hukum untuk menjamin hak serta kewajiban baik dari pihak-pihak yang berkepentingan juga untuk masyarakat secara luas (Pratiwi dkk, 2019). Akta autentik memiliki legalitas yang diakui pembuktiannya dimuka pengadilan secara formil dan materiil apabila dibuat secara tertulis serta dibuat dihadapan pejabat yang berwenang seperti Notaris (Pomantow, 2018).

Pembuatan dan penyimpanan minuta akta dengan media elektronik secara eksplisit belum ada ketentuan perundang-undangan yang mengatur. Adanya kekosongan norma inilah mengakibatkan legalitas dari aktivitas pembuatan dan penyimpanan minuta akta dengan media elektronik diragukan kepastian hukumnya apabila diterapkan, karena dianggap tidak sesuai dengan fungsi dan tujuan dari akta autentik (Sundani, 2014). Hal tersebut berpengaruh pada keautentikan minuta akta yang hanya disetarakan dengan akta dibawah tangan dan hilangnya kekuatan pembuktian yang sempurna layaknya akta autentik (Setiadewi, 2020).

Secara implisit terdapat regulasi yang memberikan peluang pengaplikasian minuta akta notaris yang disimpan secara elektronik diilndonesia yaitu pada Pasal 15 
ayat (3) UUJN Perubahan yaitu mengenai cyber notary yaitu kewenangan notaris untukmmelakukan sertifikasi transaksi secara elektronik (Kuswanto, 2017). Penerapan tersebut dimungkingkan mengingat notaris telah mengimplementasikan aplikasi elektronik sebagaimana diatur pada : a) Peraturan Menteri Hukum dan Hak Asasi Manusia Republik Indonesia Nomor 14 Tahun 2020 tentang Perubahan Kedua Atas Peraturan Menteri Hukum dan HAM Nomor 4 Tahun 2014 tentang Tata Cara Pengajuan Permohonan Pengesahan Badan Hukum dan Persetujuan Perubahan Anggaran Dasar serta Penyampaian Pemberitahuan Perubahan Anggaran Dasar dan Perubahan Data Perseroan Terbatas; b) Peraturan Menteri Hukum dan HAM Nomor 5 Tahun 2014 tentang Pengesahan Badan Hukum Yayasan; dan c) Peraturan Menteri Hukum dan Hak Asasi Manusia Republik Indonesia Nomor 6 Tahun 2014 tentang pengesahan Badan Hukum Perkumpulan dan beberapa Peraturan Menteri Hukum dan HAM lain beserta perubahannya mengenai system penggunaan aplikasi elektronik yang tersedia di Administrasi Hukum Umum Online (AHU Online) (Dewi, 2015).

Selain itu, pada perkara pidana dan perdata, alat bukti yang disimpan secara elektronik dalam perkembangan teknologi saat ini telah diakui secara sah dalam persidangan pengadilan (Adjie, 2017) yaitu berdasarkan Pasal 15 dan 66 UU ITE yang mengakui bahwa dokumen elektronik mempunyai kekuatan hukum untuk digunakan sebagai alat pembuktian yang sah di hadapan pengadilan, walaupun demikian akta notaris dikecualikan didalam ketentuan tersebut. Menurut Edmon Makarim (2020) yang merupakan dosen inti penelitian bidang Hak atas Kekayan Intelektual dan Telematika Fakultas Hukum Universitas Indonesia mengatakan bahwa pengecualian Pasal 5 ayat (4) huruf (a) dan (b) UU ITE bukan hal yang mutlak karena apabila terdapat terobosan undang- undang baru khususnya didalam UUJN disertai dinamika teknologi yang terjamin dengan sistem keterpercayaan yang baik maka ketentuan pasal tersebut dapat dikesampingkan. Sebab pasal pengecualian tidak berarti sebuah bentuk larangan. Notaris dapat melaksanakan jabatannya dengan penggunaan sistem elektronik untuk memperlancar pekerjaannya dan meminimalisir risiko dikemudian hari.

Selain UU ITE, terdapat pula Undang-Undang Nomor 8 Tahun 1997 tentang Dokumen Perusahaan; UndangUndang Nomor 43 Tahun 2009 Tentang Kearsipan (Kuswanto, 2017).

Istilah dokumen elektronik telah dikenal jauh sebelum munculnya UU ITE. Pengalihan dokumen kertas ke bentuk dokumen elektronik telah diawali oleh Undang-Undang Nomor 8 Tahun 1997 tentang Dokumen Perusahaan (selanjutnya disebut UU Dokumen Perusahaan). Pada konsiderans huruf f menyatakan bahwa pengalihan catatan dan dokumen dari kertas ke media elektronik atau dokumen yang dari awal dibuat dalam bentuk media elektronik berjalan karena mengikuti kemajuan teknologi. Dipertegas lagi pada pasal 12 ayat (1) UU Dokumen Perusahaan bahwa dokumen perusahaan mempunyai keabsahan sebagai alat bukti, walaupun telah disimpan di mikrofilm atau media elekronik lainnya (Irawan, 2018).

Keautentikan dokumen elektronik sebagai alat bukti yang sah juga diakui didalam UU ITE. Dokumen elektronik berlaku sah apabila dibuat dan disimpan sesuai dengan ketentuan UU ITE, serta adanya spesifikasi mengenai pelaksanaan sistem, sertifikasi dan transaksi elektronik. Sehingga dokumen tersebut bisa dijamin keutuhannya serta dapat dipertanggung jawabkan di muka persidangan.

Dokumen elektronik juga diakui melaluii SE Mahkamah Agung (SEMA) Nomor 14 Tahun 2010 tentang Dokumen Elektronik sebagai Kelengkapan 
Permohonan Kasasi dan Peninjauan Kembali yang selanjutnya telah mengalami perubahan menjadi SEMA 1 Tahun 2014. Surat edaran tersebut tidak mengatur mengenai alat pembuktian dalam bentuk dokumen/informasi elektronik. Melainkan berupa putusan atau dakwaan yang dialihkan pada media elektronik seperti flashdisk, compact disk ataupun dikirim via email untuk melengkapi permohonan kasasi dan peninjauan kembali. Dikarenakan metode yang lampau terdapat beberapa faktor kendala, sehingga diubahlah menjadi sistem pemeriksaan berkas dari sistem bergiliran menjadi sistem baca bersama yang diarahkan secara elektronik (Irawan, 2018).

Penyimpanan minuta akta secara elektronik memang belum diatur secara khusus pada perundang-undangan Indonesia. Namun, penyimpanan mengenai dokumen elektronik juga telah diatur di dalam UndangUndang Kearsipan. Istilah penyimpanan lebih dikenal dengan istilah pengarsipan. UndangUndang Kearsipan membedakan arsip ke dalam dua macam yaitu arsip autentik dan arsip terpercaya. Hal ini bertolakbelakang dengan makna autentik dari segi teknis dan hukum seperti yang dijelaskan diatas. Bahwa dokumen autentik merupakan dokumen yang terpercaya karena telah melalui proses pemeriksaan, pengecekan terhadap integritas data dibandingkan dengan salinan dari dokumen asli (original copy) darimana dokumen tersebut berasal.

Dalam proses pengarsipan elektronik terdapat pedoman yang dijadikan sebagai acuan yaitu berupa Peraturan Kepala ANRI Nomor 20 Tahun 2011 tentang Pedoman Autentikasi Arsip Elektronik. Autentikasi disini diartikan sebagai proses pemberian tanda dan/atau pernyataan tertulis atau tanda lainnnya yang memperlihatkan bahwa arsip yang diautentikasi merupakan data original atau copy original. Berkenaan dengan salinan arsip dapat diakui keautentikannya apabila terdapat bukti yang menyatakan itu original dari arsip aslinya. Pembuat arsip selanjutnya dapat mengidentifikasi salinan arsip mana yang sah dengan melakukan penetapan prosedur sebelumnya. Penetapan prosedur diatas berupa pemeriksaan terhadap kredibilitas data informasi yang melekat didalam dokumen tersebut supaya nilai keautentikannya dapat dipertahankan. Sehinga dokumen tersebut dapat dijadikan sebagai alat bukti berdasarkan UU Kearsipan. Apabila terdapat kelalain tidak melakukan pengecekan dan pemeriksaan dokumen arsip diatas, maka berdampak pada kekuatan hukum yang melekat kepadanya.

Selain regulasi diatas, terdapat pula undang-undang lain yang melegalkan adanya penyimpanan dokumen elektronik yaitu Undang-Undang Nomor 30 tahun 2014 tentang Administrasi Pemerintahan, Undang-Undang 25 tahun 2009 tentang Pelayanan Publik, dan Undang-Undang Nomor 14 tahun 2008 tentang Keterbukaan Informasi Publik. Hal tersebut berdampak pula pada proses legalisasi dan autentikasi yang dilakukan secara elektronik.

Seiring perkembangan zaman, maka pengaturan minuta akta yang disimpan secara elektronik dapat diimplementasikan di dunia kenotaraiatan, karena sebelumnya telah banyak implementasi di dalam lingkup kerja pemerintahan. Namun, untuk menyelenggarakan kegiatan tersebut pemerintah juga harus mulai membangun infrastuktur penyimpanan (repository) yang di dukung oleh layanan terpercaya (trust service) yang mendukung proses digitalisasi, yaitu guna mewujudkan era paperless. Perhatian pertama apabila era paperless ini diberlakukan pada dunia kenotariatan yaitu dengan menentukan prosedur untuk membuktikan suatu minuta akta atau salinan akta dapat disimpan secara aman dan terjaga keautentikannya sehingga terdapat kekuatan hukum yang melekat dan dapat menjadi alat bukti di persidangan.

Implementasi tersebut dapat tercapai apabila terdapat regulasi hukum yang 
mengaturnya seperti melakukan reaktualisasi UUJN Perubahan, UU ITE, dan pasal 1868 KUHPerdata (Wijanarko, 2015) serta diperkuat dengan adanya Peraturan Hukum dan Hak Asasi Manusia sebagai pengaturan tambahan. Serta didukung dengan pengaturan keautentikan secara teknis yang ditunjang olehhsuatuffungsi keterpercayaan sebagaimana dianut dalam Regulasi 910/2014. Denganndemikian dua paradigmaatersebut secara praktis dapat melengkapi satu sama lain.

Dari penjelasan diatas, maka harmonisasi antara penyelenggaraan dokumen elektronik beserta regulasinya dapat memberi arah dan pandangan kepada pemerintah dan notaris bahwa ada kemungkinan diterapkannya minuta akta elektronik dan dapat terjamin keautentikannya apabila berpedoman pada keautentikan yang diatur pada UU ITE serta UE Regulationn 9910/2014 tentang e-identification and trust services.

Penyimpanan minuta akta dan warkahnya merupakan tanggungjawab dari notaris sebagaimana yang telah diamanatkan oleh UUJN. Untuk meminimalisir adanya rusak atau hilangnya minuta akta dan salinan pada media cetak seperti kertas, notaris dapat menggunakan media elektronik. Minuta akta yang berbentuk media cetak, dapat diubah ke media elektronik dengan menggunakan proses scanning, selanjutnya dapat disimpan pada perangkat penyimpanan elektronik. Sedangkan penyimpanan minuta akta yang dibuat secara eletronik dapat melalui proses $e$-identification and e-authentication system pada website ataupun pada media elektronik.

Tentunya notaris dalam proses pengarsipan minuta akta dengan media elektronik harus memperhatikan aspek keamanan dan kehati-hatian. Kedua aspek tersebut dapat diaplikasikan oleh notaris dengan menggunakan media penyimpanan berupa Pita magnetik, seperti pita pada pita kaset; Piringan magnetik berbentuk disk; Piringan optic yang dapat menampung data lebih banyak dibandingkan disket; UFD
(USB Flash Disk) yaitu piranti penyimpanan data yang berbentuk seperti pena; dan Kartu memori (memory card) yang biasa digunakan pada kamera digital, ponsel, PDA; microfilm atau microfiche (Sugiarto \& Wahyono, 2014). Penyimpanan melalui media elektronik telah diakui didalam hukum acara pidana melalui Surat MA kepada Menkeh Nomor 39/TU/88/102/Pid tanggal 14 Januari 1988 yang menjelaskan bahwa microfilm atau microfiche dapat dijadikan sebagai alat bukti sah dan dapat menjadi pengganti alat bukti surat, dengan syarat bahwa microfilm tersebut telah dijamin keautentikanya dengan dilakukan penelusuran dari registrasi maupun berita acara (Pribadi, 2018).

Mekanisme penyimpanan minuta akta dari media cetak ke media elektronik diawali dengan proses scanning dengan menggunakan scanner. Scanner adalah alat yang membaca data berupa sinar terang, kemudian menangkap teks atau gambar yang terpantul pada suatu matriks sel-sel foto elektrik (Suyanto, 2005). Hasil scanning kemudian disusun secara rapi serta sistematis dan disimpan dengan file ekstensi berupa Portable Document Format (selanjutnya disebut PDF). Pada file PDF, notaris dapat mengunci file tersebut agar tidak ada orang yang mengubahnya sebagai upaya dalam menjaga keamanannya. File minuta akta yang tersimpan di perangkat komputer atau laptop dipindah ke media penyimpanan elektronik sebagaimana yang telah disebutkan diatas. Selanjutnya dapat disimpan pada brankas anti kebarakan dan anti lembab. Harapan dari minuta akta yang tersimpan pada media elektonik dapat mewakili minuta akta yang rusak atau hilang apabila terdapat pihak yang berkepentingan meminta salinan atau dapat menjadi alat bukti pendukung dalam proses peradilan.

Minuta akta yang telah tersimpan secara elektronik secara hukum tidak memenuhi kekuatan pembuktian selayaknya akta notariil yang dibuat secara konvensional, 
karena tidak memenuhi syarat otentitas yang diatur dalam pasal 1 ayat 1 UUJN dan pasal 1868 KUHPerdata. Hal ini berdampak pada kekuatan hukumnya yang hanya bisa berfungsi sebagai back up dan bukan sebagai salinan (Putri \& Budiono, 2019). Untuk itu perlu adanya perbaruan substansi UUJN dan Pasal 1868 KUHPerdata.

Khusus aspek keamanan dan pertanggungjawaban, maka diperlukan penyelenggaraan sistem yang aman, handal, serta dapat dipertanggungjawabkan. Sehingga minuta akta yang disimpan secara elektronik memiliki kekuatan pembuktian yang sah dan mengikat di kemudian hari. Hal tersebut dapat terjadi apabila sistem penyelenggaraannya bersifat akuntabel, sehingga nilai atau bobot keautentikannya mempunyai nilai yang lebih tinggi. Pada penyimpanan minuta akta secara elektronik belum ada jaminan keamanan dari resiko perubahan yang dilakukan pihak lain. Bisa jadi minuta akta yang tersimpan secara elektronik, terdapat beberapa substansi yang berbeda dari dokumen aslinya. Sehingga bentuk scanning minuta akta tidak cukup dilakukan dalam bentuk pdf semata. Melainkan perlu adanya kejelasan dan jaminan keautentikan yang melekat pada minuta akta tersebut.

Berdasarkan pendekatan functional equivalent approach, yaitu mempersamakan secara fungsional minuta akta elektronik dengan bukti tulisan yang ada pada media cetak serta minuta akta yang dibuat secara elektronik sejak awal pembuatan setidaknya haruslah memenuhi tiga dasar (Makarim, 2013), yaitu: (i) Minuta akta tersebut dianggap tertulis apabila mudah disimpan serta mudah dicari atau diketemukan; (ii) Minuta akta tersebut diakui original apabila selama penyimpan, pencarian, serta dibaca kembali substansinya tidak mengalami suatu perubahan, sehingga keautentikan dan kredibilitasnya terjaga; (iii) Minuta akta tersebut dianggap bertanda tangan apabila terdapat informasi yang menjelaskan adanya subjek hukum yang bertanggungjawab diatasnya atau terdapat sistem autentikasi yang reliable yang menjelaskan iidentitas dan otorisasi ataupun verifikasi dari pihak tersebut.

Mengacu kepada substansi Pasal 6 UU ITE, bahwa minuta akta dalam bentuk dokumen elektronik dianggap sah apabila : Pertama, dapat diakses, artinya minuta akta yang dibuat secara digital dapat ditemukan dan diakses oleh sistem elektronik; Kedua, Dapat ditampilkan, artinya minuta akta tersebut dapat ditampilkan olehhsistem elektronik; Ketiga, keutuhannyan terjaga, artinya keutuhan isi dari minuta akta tersebut dapat terjamin melalui proses pengecekan, pemeriksaan dan pengupasan (analisis); Keempat, bersifat akuntabel, artinya hal-hal yang diperoleh mulai dari proses pembuatan akta hingga penyimpanan dan apabila adanya proses pengiriman/laporan misalnya kepada MPD maka dapat dijamin keasliannya.

Maka, untuk menjaga teknis keautentikan dari minuta akta elektronik dibutuhkan dukungan berupa penggunaan infrastuktur yang berinduk kepada root CA pemerintah atau Nasional dan perlu penggunaan algoritma enkripsi nasional untuk memperjelas hal itu (Makarim, 2015). Selain itu, perlu pula sistem e-identification serta trust service sebagaimana yang terdapat pada UE Regulation 910/2014 mengenai pengaturan keabsahan pada dokumen elektronik.

Mengenai penyimpanan akta autentik konvensional dalam hal keamanan mempunyai kelebihan dari segi hukum dan kelemahan yang ditinjau dari segi ekonomis. Akta autentik berdasarkan hukum pada umumnya dibuat dan disimpan secara konvensional. Sehingga keamanan mengenai keautentikan akta tersebut terjamin karena telah diatur formalitas dan tata cara pembuatannya oleh perundang-undangan. Artinya keamanan dari penyimpanan akta autentik adalah kepastian hukum yang telah terukur dan terjamin. Sedangkan kelemahan 
dari segi ekonomis, media kertas rawan terjadi kerusakan atau kehilangan baik karena kelalaian notaris itu sendiri atau karena bencana alam. Ketika akta autentik tersebut rusak maka tidak dapat dilakukan backup agar akta tersebut kembali utuh. Sehingga hal ini dapat menyulitkan notaris dan pihak yang berkepentingan terhadap akta tersebut.

Apabila terjadi rusak/hilang/musnahnya minuta akta maka dapat digantikan dengan salinannya. Kedudukan salinan akta tersebut diatur dalam ketentuan pasal 1889 KUHPerdata yang menyatakan bahwa apabila akta asli tidak ada lagi, maka salinannya bisa digunakan sebagai alat bukti dalam perkara perdata dengan adanya ketentuan. Sedangkan upaya hukum yang dilakukan notaris apabila diketahui minuta akta tidak ada lagi yaitu dengan membuat laporan kehilangan minuta akta yang tercatat di dalam Repertorium dan Klaper akta kepada kepolisian dengan alasan yang sebenarnya. Untuk pihak yang memegang salinan akta, agar aktanya dapat disamakan dengan asli akta yaitu dengan mengajukan permohonan Penetapan Pengadilan Negeri agar salinan tersebut dibenarkan oleh hakim berdasarkan pengakuan para pihak sendiri (Priyandini, 2018).

Untuk meminimalisir adanya hilangnya bukti minuta akta dan salinanya, maka dapat dilakukan dengan solusi penyimpanan dalam bentuk elektronik yang dalam hal keamanan mempunyai kelebihan dari segi ekonomis yaitu (i) Menggunakan perangkat computer; (ii) Proses pencarian sangat cepat; (iii) Adanya access control, sehingga tidak mudah diakses oleh siapapun kecuali yang memiliki kunci untuk membuka dan mengolah; (iv) Efesiensi tempat sebab tidak membutuhkan banyak ruangan untuk menyimpan; (v) Terdapatnya salinan arsip dalam bentuk elektronik; (vi) Keamanan akses arsip elektronik dari pihak yang tidak berkepentingan; (vii) Sebagai fasilitas backup arsip-arsip vital; dan (viii) Kecepatan penyajian informasi yang terekam dalam arsip elektronik.

Sedangkan kelemahan dari dokumen elekronik sendiri mempunyai kerentanan keamanan dari virus dan terhadap adanya perubahan. Solusi kerentanan dari virus dapat disediakan perangkat antivirus sebagai upaya pencegah kerusakan atau hilangnya dokumen, sedangkan upaya pencegahan terhadap adanya perubahan dapat melalui proses e-identification and e-authentication sytem yang mencakup trust services provide yaitu berupa penyelenggaraan jasa sertifikat berdasarkan kualifikasi agar keautentikannya terpercaya.

Dari regulasi diatas, maka dapat memberikan pandangan bagi pemerintah dan notaris khususnya. Peluang implementasi penyimpanan minuta akta tidak mustahil dilakukan apabila terdapat peraturan perundang-undangan yang mengatur, baik mengatur mengenai mekanisme pembuatan, penyimpanan, dan kekuatan keuatentikannya. Selain Undang-Undang maka perlu dibarengi adanya teknologi yang mendukung agar pengaplikasian penyimpanan minuta akta secara elektronik dapat berjalan efektif dan efisien serta terjaga pula keautentikannya.

\section{SIMPULAN}

Keautentikan didalam hukum acara perdata Indonesia dan Belanda terkait suatu dokumen elektronik harus mencakup secara yuridis dan teknis, sehingga dokumen tersebut secara formil dan materiil dapat dijadikan sebagai alat bukti yang memiliki kekuatan hukum di muka pengadilan. Keautentikan di Belanda telah terukur dengan adanya harmonisasi antara regulasi dan teknologi yang reliabel. Sedangkan di Indonesia keautentikan dokumen elektronik mengecualikan akta notaris atau akta lainnya yang secara undang-undang mewajibkan akta tersebut dibuat secara fisik.

Legalitas penyimpanan minuta akta secara elektronik masih belum diakui 
eksistensinya, legalitas yang diakui di Indonesia saat ini hanya berupa dokumen elektronik yang telah di atur di beberapa regulasi, dimana setiap regulasi memiliki penentu tingkat keautentikan yang berbedabeda. Konseptual mekanisme penyimpanan minuta akta elektronik dapat dilakukan dengan dua jenis yaitu: a) dari media cetak kemudian dilakukan upaya scanning untuk dirubah ke bentuk elektronik; dan b) dari awal telah dibuat dalam media elektronik dengan syarat adanya e-dentification dan e-autentication sehingga terjamin orisinalitasnya. Keduanya selanjutnya disimpan ke dalam media compact disk atau media elektronik lain. Mengenai kualitas pembuktian, keduanya belum dapat dijadikan sebagai alat bukti autentik kecuali pemerintah telah membuat sistem identifikasi elektronik dan trust service serta dipayungi oleh regulasi hukum mengatur penentu keautentikan minuta akta elektronik.

\section{DAFTAR PUSTAKA}

Undang-Undang Nomor 8 Tahun 1997 tentang Dokumen Perusahaan

Undang-Undang Nomor 11 Tahun 2008 tentang Informasi dan Transaksi Elektronik

Undang-Undang Nomor 14 tahun 2008 tentang Keterbukaan Informasi Publik

Undang-Undang Nomor 43 Tahun 2009 Tentang Kearsipan

Undang - Undang Nomor 30 Tahun 2004 tentang Jabatan Notaris sebagaimana telah diubah dengan Undang-Undang Nomor 2 Tahun 2014

Undang-Undang Nomor 30 tahun 2014 tentang Administrasi Pemerintahan

Undang-Undang 25 tahun 2009 tentang Pelayanan Publik

Peraturan Kepala ANRI Nomor 20 Tahun 2011 tentang Pedoman Autentikasi Arsip Elektronik

Surat Edaran Mahkamah Agung
(SEMA) Nomor 14 Tahun 2010 tentang Dokumen Elektronik sebagai Kelengkapan Permohonan Kasasi dan Peninjauan Kembali sebagaimana telah dirubah menjadi SEMA 1 Tahun 2014.

Adjie, Habib. (2017). Konsep Notaris Mayantara Menghadapi Tantangan Persaingan Global, Jurnal Hukum Respublika, Vol. 16 (2), 201-218

Apriana, Rifka Annisa. (2018). Kekuatan Hukum Back Up Minuta Akta Yang Disimpan Di Dalam Media Penyimpanan Data Komputer oleh Notaris Sebagai Alat Bukti Menurut Hukum Acara Perdata. Tesis Magister Kenotariatan Universitas Sultan Agung, diakses (online) melalui (https://eprints.uns.ac.id/21780/) diakses tanggal 22 Oktoebr 2020

Dewi, Amelia Sri Kusuma. (2015). Penyelenggaraan RUPS Melalui Media Elektronik Terkait Kewajiban Notaris Melekatkan Sidik Jari Penghadap, Jurnal Arena Hukum, Vol. 8 (1), 108-126

Imtiyaz,Lana., Santoso, Budi., \& Prabandari, Adya P. (2020). Reaktualisasi UndangUndang Jabatan Notaris Terkait Digitalisasi Minuta Akta Oleh Notaris. Jurnal Notarius, No. 1 Vol. 13, 97-110 Irawan, Sofyan Adi. (2018). Eksistensi Dokumen Elektronik Di Persidangan Perdata. Artikel diterbitkan, (Online), diakes melalui (https://www.mahkamah agung.go.id/id/artikel/3048/eksistensidokumen-elektronik-di-persidanganperdata), diakses pada tanggal 14 September 2020)

Kuswanto, Mohamat Riza. (2017). Urgensi Penyimpanan Protokol Notaris dalam Bentuk Elektronik dan Kepastian Hukumnya di Indonesia. Jurnal Repertorium, 4 (2), 62-69.

Makarim, Edmon. (2013). Buku Seri Hukum Telematika: Notaris dan Transaksi Elektronik. Jakarta: Raja 
Grafindo Persada.

Makarim, Edmon. (2015). Keautentikan Dokumen Publik Elektronik dalam Adminitrasi Pemerintahan dan Pelayanan Publik. Jurnal Hukum dan Pembangunan, (4), 508-571

Makarim, Edmon. (2020). Layanan Notaris Secara Elektronik dalam Kedaruratan Kesehatan Masyarakat. Diakses (online) melalui (https://law. ui.ac.id/v3/layanan-notaris-secaraelektronik-dalam-kedaruratankesehatan-masyarakat-oleh-dredmon-makarim-s-kom-s-h-11-m/) diakses tanggal 22 Oktober 2020

Mamudji, Sri. (2005). Metode Penelitian dan Penulisan Hukum. Jakarta : Badan Penerbit Universitas Indonesia

Marzuki, Peter Mahmud. (2011). Penelitian Hukum. Jakarta : Kencana.

Pratiwi, Sastri Hasnuri., Fendri Azmi., \& Bennie Beatrix. (2019). Authority and Position Of Notary Deed in the Land Sector. Multicultural and Multiregious Understanding (IJMMU), 6 (5), 391- 403

Pribadi, Insan. (2018). Legalitas Alat Bukti Elektronik Dalam Sistem Peradilan Pidana. Jurnal Lex Renaissance, 3 (1), 109-124.

Priyandini, Astari. (2018). Kedudukan Hukum Salinan Akta Notaris Dalam Hal Terjadi Musnahnya Minuta Akta. Justitia Jurnal Hukum, 2 (1), 66-86.

Pomantaw, Vivien. (2018). Akibat Hukum Terhadap Akta Otentik Yang Cacat Formil Berdasarkan Pasal 1869 KUHPerdata, Jurnal Lex Privatum, Vol. VI (7), 90-98

Putri, Chiska Claudia.(2019). Penyimpanan Protokol Notaris Secara Elektronik dalam Konsep Cyber notary. Tesis Magister Kenotariatan Universitas Sriwijaya, diakses (online) melalui (https://repository.unsri.ac.id/26468/3/ RAMA $74102 \quad 02022681721048$ 0025106204_01_FRONT_REF.pdf) diakses tanggal 21 Oktober 2020.
Putri, Cyndiarnis Cahyaning \& Budiono Abdul Rachmad. (2019). Konseptualisasi Dan Peluang Cyber notary Dalam Hukum., Jurnal Ilmiah Pendidikan Pancasila dan Kewarganegaraan, Vol. 4 (1), 29-36

Rositawati, Desy., Utama, I Made Arya Utama., \& Kasih, Desak P. D. (2017). Penyimpanan Protokol Notaris secara elektronik dalam Kaitan Cyber notary. Jurnal Acta Comitas, 2, 172-182

Setiadewi, Kadek. (2020). Legalitas Akta Notaris Berbasis Cyber notary Sebagai Akta Otentik. Jurnal Komunikasi Hukum (JKH) Universitas Pendidikan Ganesha, Vol. 6 (2), 126-134

Simorangkir., Erwin, Rudi T., \& Prasetyo, JT. (2013). Kamus Hukum. Jakarta : Sinar Grafika.

Soemitro, Ronny H. (2001). Metodologi Penelitian Hukum dan Jurimetri. Jakarta: Ghalia Indonesia.

Subekti, R. \& Tjitrosudibio, R. (2009). Kitab Undang-Undang Hukum Perdata. Jakarta: Pradnya Paramita.

Subrayogo, Imam. (2001). Metodologi Penelitian Sosial-Agama. Bandung: Remaja Rosdakarya.

Suharso \& Retnoningsih,Ana. (2014). Kamus Besar Bahasa Indonesia. Semarang: Widya Karya.

Sugiyanto, Qisthi Fauziyyah \& Handoko, Widhi. (2019). Peluang dan Tantangan Calon Notaris dalam Menghadapi Perkembangan Disrupsi Era Digital, Jurnal Notarius, Vol. 12 (2), 656-668

Sugiarto, Agus \& Wahyono, Teguh. (2014) Manajemen Kearsipan Elektronik. Yogyakarta : Gava Media.

Sundani, Tiska. (2017). Analisis Hukum atas Penggunaan dan Pembuatan Akta Notaris Secara Elektronik. Premise Law Jurnal. Vol. 1, 1-20

Suyanto, M. (2005). Multimedia: Alat untuk Meningkatkan Keunggulan Bersaing. Yogyakarta : Andi. 
Syamsir., Rahmi, Elita., \& Yetniwati. (2019). Prospek Cyber notary Sebagai Media Penyimpanan Pendukung Menuju Profesionalisme Notaris. Jurnal Recital Review, 1 (2), 132-147.

Tobing, G.H.S. Lumban. (1983). Peraturan Jabatan Notaris. Jakarta : Erlangga.

Triyanti. (2015). Kekuatan Pembuktian Dokumen Elektronik Sebagai Pengganti Minuta Akta Notaris. Jurnal Repertorium, 2 (2), 20-30

Wijanarko, Fahma Rahman. (2015). Tinjauan Yuridis Pemberlakuan Cyber notary di Indonesia Berdasarkan UndangUndang Nomor 2 Tahun 2014 tentang Perubahan atas Undang-Undang Nomor 30 Tahun 2004 tentang Jabatan Notaris Jurnal Repertorium, Vol. 2 (2), 7-19 